\title{
Periodic operation applied to the kinetic study of $\mathrm{CO}_{2}$ methanation
}

\author{
Michel Marwood*, Frédéric Van Vyve, Ralf Doepper, \\ Albert Renken
}

Institute of Chemical Engineering, Swiss Federal Institute of Technology, CH-1015 Lausanne, Switzerland

\begin{abstract}
Periodic operation was applied to the $\mathrm{CO}_{2}$ methanation reaction at $383 \mathrm{~K}$ on $2 \% \mathrm{Ru} / \mathrm{TiO}_{2}$. A continuous feed recycle reactor combined with a diffuse reflectance infrared cell and a mass spectrometer allowed to follow simultaneously the gas phase $\mathrm{CO}_{2}$ and $\mathrm{CH}_{4}$ as well as the adsorbed species $(\mathrm{CO})_{\mathrm{a}}$ and (formate) ${ }_{\mathrm{a}}$. Experiments consisting of periodic variations of $\mathrm{CO}_{2}$ in the hydrogen feed showed response curves with maxima/minima shifted in time in the sequence $\mathrm{CO}_{2}$, (formate $)_{\mathrm{a}} \rightarrow(\mathrm{CO})_{\mathrm{a}} \rightarrow \mathrm{CH}_{4}$. Similar delays measured for the $(\mathrm{CO})_{\mathrm{a}}$ formation and hydrogenation indicate that both of these processes are limiting the overall reaction rate. A kinetic model was proposed and verified under periodic conditions. The main experimental trends, which are pronounced time lags between $\mathrm{CO}_{2},(\mathrm{CO})_{\mathrm{a}}$ and $\mathrm{CH}_{4}$, could be described satisfactorily.
\end{abstract}

\section{Introduction}

Usually heterogeneous catalytic reactions are studied under steady-state conditions, leading to overall kinetic models often based on the assumption of an ideal surface and one rate limiting step. It can easily be shown $[1,2]$ that the assumption of a multistep control leads to expressions resembling those established with a unique rate determining step. The overall lumped kinetic model does not reflect a unique mechanistic physicochemical reality.

It has been shown [3] that the transient behaviour of a reaction is strongly influenced by the elementary step rate constants. Therefore dynamic experiments are used in order to distinguish between different models describing stead $y$-state behaviour. Kinetic studies with simultaneous surface and gas phase measurements considerably increase the amount of information available for the establishment of a kinetic model. Yet it is important to distinguish reactive adsorbed species from spectator surface species that do not participate

${ }^{*}$ Corresponding author. 
in the reaction [4]. Dynamic experiments can be used as a tool to understand the role of these observed species.

In this work in situ infrared surface analysis is performed under dynamic cyclic conditions. The aim is to understand the role of the observed surface species in order to establish a reaction model with physicochemical reality and to test this model under these discriminating conditions.

In previous works, Prairie et al. [5-7] showed the advantages of coupling a diffuse reflectance infrared cell with a continuous feed recycle reactor for in situ kinetic and mechanistic studies. In this configuration it is possible to benefit from all the advantages of in situ diffuse reflectance infrared spectroscopy (DRIFTS) as well as from those of a gradientless reactor that permits meaningful kinetic studies. These authors have applied this technique to the transient and steady-state studies of low temperature $\mathrm{CO}_{2}$ methanation on titania supported ruthenium.

The main features about this reaction are summarized in [8]. $\mathrm{CO}_{2}$ hydrogenation is much more selective for $\mathrm{CH}_{4}$ than is $\mathrm{CO}$ hydrogenation. Higher selectivities for $\mathrm{CH}_{4}$, higher reaction rates and lower reaction temperatures are thought to result from favorable distribution of adsorbed $\mathrm{CO},(\mathrm{CO})_{\mathbf{a}}$, and adsorbed carbon species $(\mathrm{C})_{\mathbf{a}}$, during $\mathrm{CO}_{2}$ methanation as compared to $\mathrm{CO}$ methanation. Adsorbed formate species, (formate) ${ }_{a}$, are observed by infrared spectroscopy and appear to exist mainly on the support. Furthermore, $(\mathrm{CO})_{\mathrm{a}}$ was detected and identified as a major metal-adsorbed intermediate [8-10].

Prairie et al: [5-7] proposed a mechanism where the observed surface ( $\mathrm{CO})_{\mathrm{a}}$ and (formate) ${ }_{\mathrm{a}}$ are accumulated reservoirs en route to $\mathrm{CH}_{4}$, and where the $(\mathrm{CO})_{\mathrm{a}}$ hydrogenation step is rate controlling.

\section{Experimental}

\subsection{Material}

The apparatus (Fig. 1) consisted of a recycle reactor linked to a controlled-environment DRIFTS cell. The recycle reactor was composed of a heatable fixed-bed coupled via an external recycle loop with a water trap $\left(+4^{\circ} \mathrm{C}\right)$. The DRIFTS cell held $70-100 \mathrm{mg}$ of catalyst while $4.0 \mathrm{~g}$ were placed into the fixed-bed reactor. Two thermocouples, one located in the catalyst in the fixed bed and the other in the catalyst in the DRIFTS cell, were used with proportional-integral-derivative (PID) temperature controllers to ensure that both catalyst charges operate at the same temperature.

As in [5-7] the cell can be considered as a window into the reactor, providing a representative view of the entire catalyst surface under process conditions. In this setup the cell was placed outside the recycle loop. This avoided high pressure drops in the DRIFTS cell due to high recycled flows. Furthermore due to the low catalyst loading in the DRIFTS cell, its contribution to the measured conversion is negligible. An oscillating membrane pump maintained a flow-rate of $3.6 \mathrm{~N} 1 / \mathrm{min}\left(25^{\circ} \mathrm{C}, 1 \mathrm{bar}\right)$ in the recycle loop, thus providing good back-mixing in the reactor system with feed flow-rates of $90 \mathrm{~N} \mathrm{ml} / \mathrm{min}$. A step response tracer experiment produced a response curve characterized by a mean residence time of $1.75 \mathrm{~min}$ for a feed flow-rate of $90 \mathrm{~N} \mathrm{ml} / \mathrm{min}$. 
Feed was supplied through one of two banks of mass flow controllers that could be selected using a low-volume, four way switching valve across which pressure and flow-rate were equilibrated to avoid surges during switching. Reactor effluent composition was determined with a Balzers QMG 420 quadruple mass spectrometer coupled with a twostage continuous atmospheric sampling system. The DRIFTS cell (Harrick HVC-DRP vacuum chamber with DRA-2CO diffuse reflectance accessory) was located in a Nicolet $710 \mathrm{FT}$-IR spectrometer equipped with a mid-range MCT detector and a $\mathrm{KBr}$ beamsplitter. The instrument was operated at a scan speed of $1 \mathrm{scan} / \mathrm{s}$ and a resolution of $4 \mathrm{~cm}^{-1}$. A number of 20 coadded interferograms was used to obtain spectra during periodic operations. This number was a compromise between an acceptable signal-to-noise ratio and the periodic time scale.

The water trap consisted of a $20 \mathrm{ml}$ glass U-tube filled with $1 \mathrm{~mm}$ glass beads. It was filled with $0.5 \mathrm{ml} \mathrm{H}_{2} \mathrm{O}$ before each experiment and kept at $4^{\circ} \mathrm{C}$ in order to maintain a constant water partial pressure ( $8.1 \mathrm{mbar})$ in the recirculating gas.

$\mathrm{CO}_{2}(99.995 \%), \mathrm{H}_{2}(99.9999 \%)$ and $\mathrm{He}(99.9999 \%)$ were used after passing through Oxisorb traps that reduce oxygen impurity levels to less than $0.1 \mathrm{ppm}$.

\subsection{Methods}

\subsubsection{Catalyst preparation}

The catalyst consisted of ruthenium (2.0 wt.-\%) dispersed on $\mathrm{TiO}_{2}$ (Degussa P25). Its preparation and characterization have been described elsewhere [11].

Standard catalyst pretreatment consisted of heating the catalyst to $225^{\circ} \mathrm{C}$ in flowing $40 \%$ $\mathrm{O}_{2}$ for 1 hour followed by a brief purge in $\mathrm{He}$ and a reduction in $40 \% \mathrm{H}_{2}$ at $225^{\circ} \mathrm{C}$. The catalyst was then cooled to $110^{\circ} \mathrm{C}$ in $40 \% \mathrm{H}_{2}$ and left to stabilize for 1 hour, after which it was exposed to $\mathrm{CO}_{2} / \mathrm{H}_{2} / \mathrm{He}(1: 4: 5)$. Within 15 minutes, methanation activity rose to a quasi-steady-state, then slowly fell to $80 \%$ of its original value over a period of 4 hours, after which it remained constant for a period of at least 96 hours. All experimental data were recorded during this latter period.

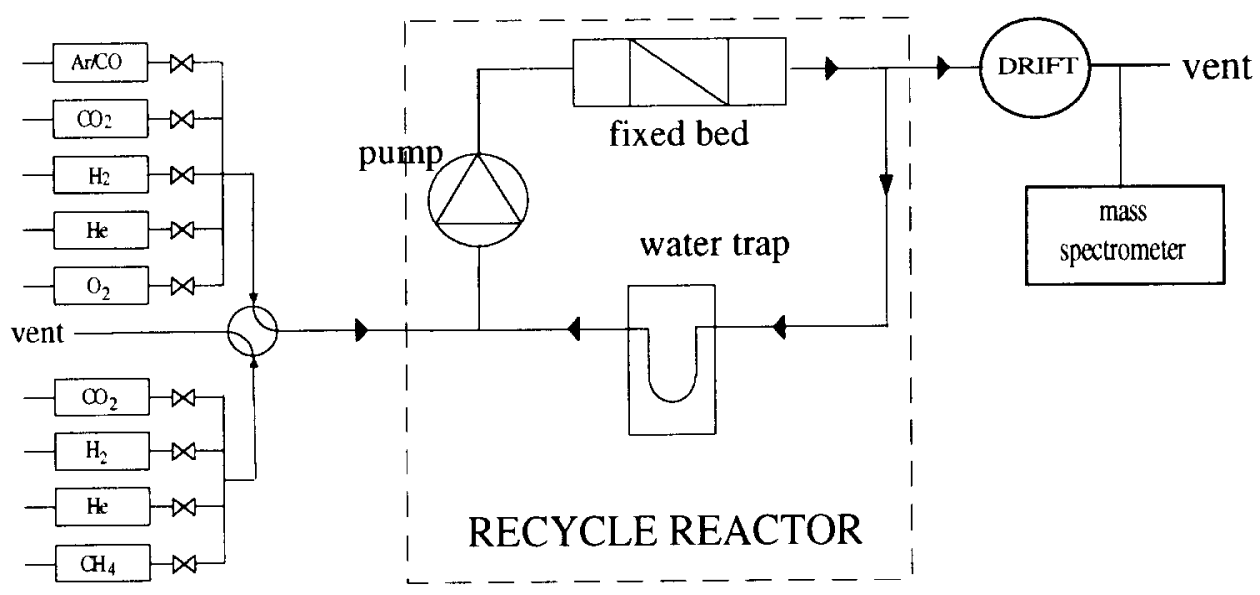

Fig. 1. Experimental set-up. 


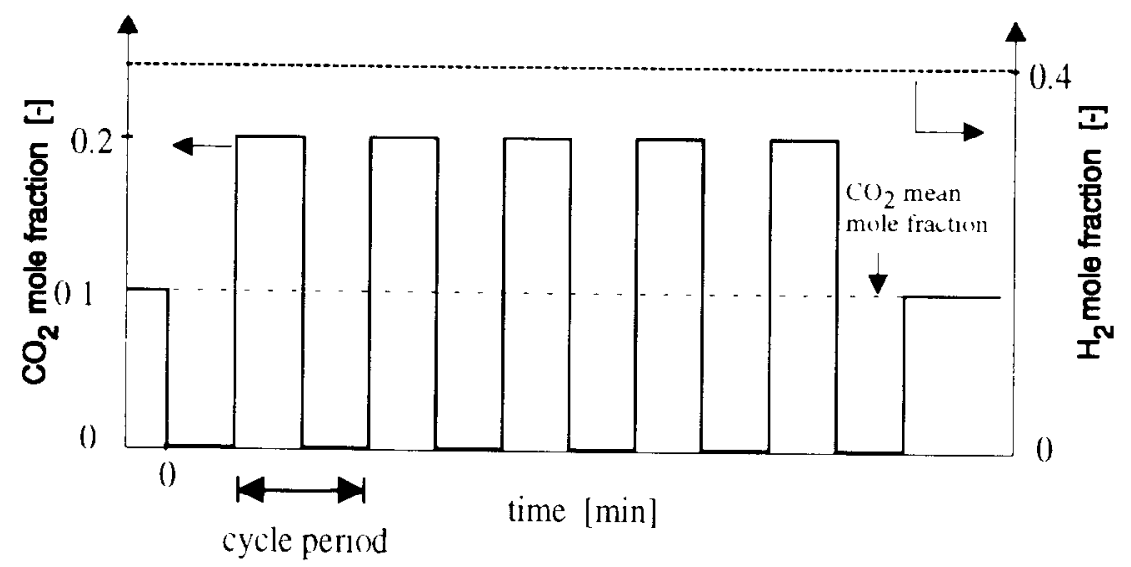

Fig. 2. Inlet function (schematic).

\subsubsection{Periodic experiments}

The experiment consisted of cyclic variations of $\mathrm{CO}_{2}$ in the feed ( feed $=\mathrm{H}_{2} / \mathrm{He}$ ). Feed compositions were chosen such as to maintain an average mole fraction over a period equal to $\mathrm{CO}_{2} / \mathrm{H}_{2} / \mathrm{He}=(1: 4: 5)$. All data presented are normalized by the corresponding stationary data at this average mole fraction composition. A series of five cycles was taken for each cycle period, followed by a 1 hour stabilization at $\mathrm{CO}_{2} / \mathrm{H}_{2} / \mathrm{He}=(1: 4: 5)$ before performing the next series of cycles (Fig. 2).

IR spectra are represented in Kubelka-Munk ( $\mathrm{K}-\mathrm{M}$ ) form, with a reference spectrum consisting of the clean catalyst in flowing $\mathrm{H}_{2}$ multiplied by a factor 20 , as described in ref. [6]. The $(\mathrm{CO})_{\mathrm{a}}$ data consist of the integral of the $(\mathrm{CO})_{\mathrm{a}}$ peaks between $2075-1800 \mathrm{~cm}^{-1}$, while the (formate) data consist of the $1552 \mathrm{~cm}^{-1}$ peak height.

\section{Results and discussion}

\subsection{Identification of adsorbed intermediates}

Fig. 3a shows the spectrum of $2 \% \mathrm{Ru} / \mathrm{TiO}_{2}$ exposed at $110^{\circ} \mathrm{C}$ to flowing $40 \% \mathrm{CO}$ for 10 min followed by a $10 \mathrm{~min} H e$ purge to eliminate the gas phase absorbance bands. The large band at $2050 \mathrm{~cm}^{-1}$ is characteristic of linearly bound $(\mathrm{CO})_{\mathrm{a}}$ on $\mathrm{Ru}^{0}[8,10,12-16]$ while the asymmetric broadening below $2000 \mathrm{~cm}^{-1}$ corresponds to linearly bonded $(\mathrm{CO})_{\mathrm{a}}$ with ruthenium of different oxidation states. The small $2133 \mathrm{~cm}^{-1}$ band is attributed to a multicarbonyl species [16].

Fig. $3 \mathrm{~b}$ shows the spectrum of $\mathrm{TiO}_{2}$ at $110^{\circ} \mathrm{C}$ where $2 \mathrm{ml}$ of $\mathrm{HCOOH}$ were injected into the flowing He carrier. Two large bands at $1555 \mathrm{~cm}^{-1}$ and $1360 \mathrm{~cm}^{-1}$ arise from asymmetric and symmetric $\mathrm{O}-\mathrm{C}-\mathrm{O}$ stretching vibrations of adsorbed (formate) ${ }_{\mathrm{a}}$ species $[8-10,13,17]$. The $1379 \mathrm{~cm}^{-1}$ and $2870 \mathrm{~cm}^{-1}$ smaller bands are attributed to the $\mathrm{CH}$ bending and stretching vibrations. The two smaller bands at $2948 \mathrm{~cm}^{-1}$ and $2730 \mathrm{~cm}^{-1}$ result [17] from combinations or overtones of $\nu_{(\mathrm{a}) \mathrm{CO}_{2}^{-}}+\delta_{\mathrm{CH}}\left(2948 \mathrm{~cm}^{-1}\right)$ and $\nu_{(s) \mathrm{CO}_{2}^{-}}+\delta_{\mathrm{CH}}\left(2730 \mathrm{~cm}^{-1}\right)$. The 


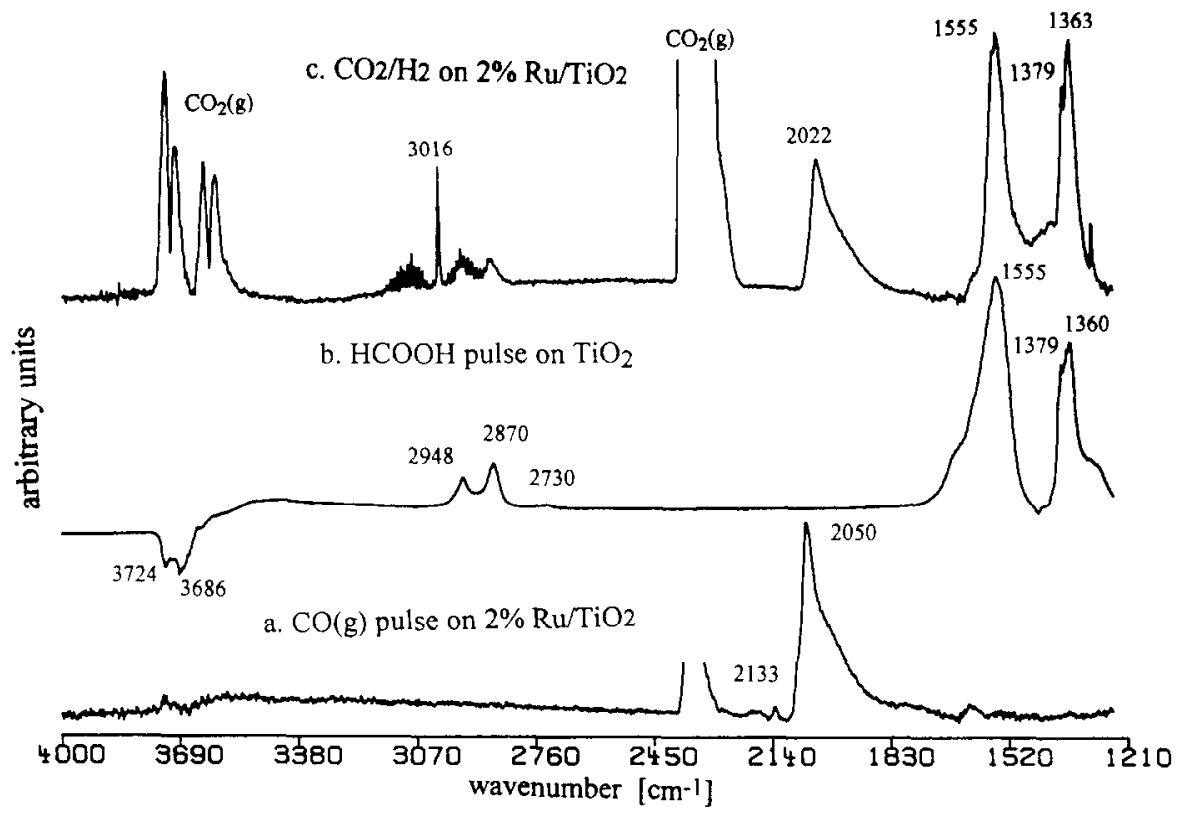

Fig. 3. IR spectra of adsorbed intermediates.

two negative bands at $3724 \mathrm{~cm}^{-1}$ and $3686 \mathrm{~cm}^{-1}$ correspond to a decrease of free hydroxyls on the $\mathrm{TiO}_{2}$ surface. This decrease is due to a formate formation by a condensation mechanism between $\mathrm{HCOOH}$ and these hydroxyls.

Fig. $3 \mathrm{c}$ shows the spectrum obtained on $2 \% \mathrm{Ru} / \mathrm{TiO}_{2}$ under steady-state $\mathrm{CO}_{2}$ methanation conditions. Bands characteristic of (formate) ${ }_{a}$ are observed at 1360, 1379, 1555, 2870, $2948 \mathrm{~cm}^{-1}$ together with a large $(\mathrm{CO})_{\mathrm{a}}$ band at $2022 \mathrm{~cm}^{-1}$. Gaseous $\mathrm{CH}_{4}$ is characterized by a band at $3016 \mathrm{~cm}^{-1}$ associated to its rotational structure.

\subsection{Periodic operation}

In Fig. 4 the gas phase $\mathrm{CO}_{2}$ and $\mathrm{CH}_{4}$ are represented together with surface $(\mathrm{CO})_{a}$ and (formate) a for a 20 minute cycle period and a symmetrical split. The $\mathrm{CO}_{2}$ conversion under these conditions is less than $3 \%$ and the $\mathrm{CO}_{2}$ signal corresponds to the residence time distribution of the gas phase. This was verified by using an inert argon tracer.

As can be seen in Fig. $4, \mathrm{CH}_{4}$, the final reaction product, is still produced when the $\mathrm{CO}_{2}$ concentration in the gas phase is negligible. $\mathrm{As} \mathrm{CH}_{4}$ does not adsorb on the catalyst under reaction conditions, this phenomenon has to be attributed to the reaction of strongly adsorbed surface intermediates. This hypothesis is confirmed by the fact that the $\mathrm{CH}_{4}$ production rate remains constant for about 2 minutes while the $\mathrm{CO}_{2}$ concentration decreases.

The concentration of the $\mathrm{CH}_{4}$ precursor on the catalyst should show the same dynamic behaviour as the $\mathrm{CH}_{4} \cdot(\mathrm{CO})_{\mathrm{a}}$ is consistent with this assumption, as its concentration remains constant for about the same time period as the $\mathrm{CH}_{4}$. The fact that the $(\mathrm{CO})_{\mathbf{a}}$ concentration can remain constant while $\mathrm{CH}_{4}$ is formed and $\mathrm{CO}_{2}$ is decreasing indicates the presence of 


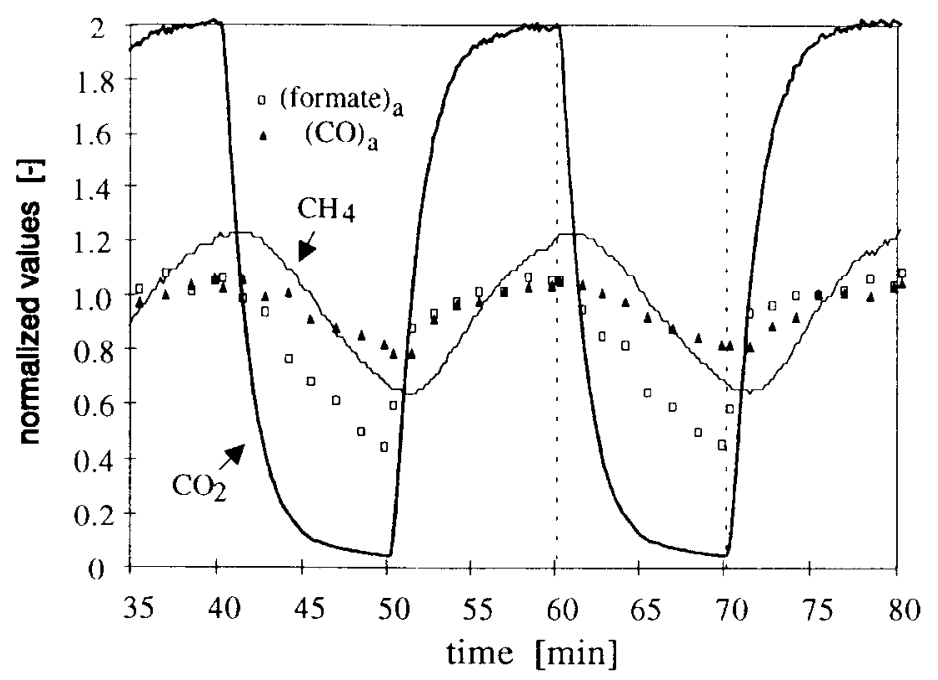

Fig. 4. Response curves to periodic $\mathrm{CO}_{2}$ feed variations.

one or more slow kinetic steps to form the $(\mathrm{CO})_{\mathbf{a}}$. The slow desorption/decomposition of the (formate) ${ }_{\mathrm{a}}$ could be responsible for the refurnishing of this reacting $(\mathrm{CO})_{\mathrm{a}}$.

If the amplitudes of the different signals are adjusted to be comparable (Fig. 5), a clear $\mathrm{CO}_{2},(\mathrm{CO})_{\mathrm{a}}, \mathrm{CH}_{4}$ time sequence is observed between the maxima of these signals. Also the shape of the $\mathrm{CO}_{2}$ signal is gradually transformed into a sinus form through the reaction sequence.

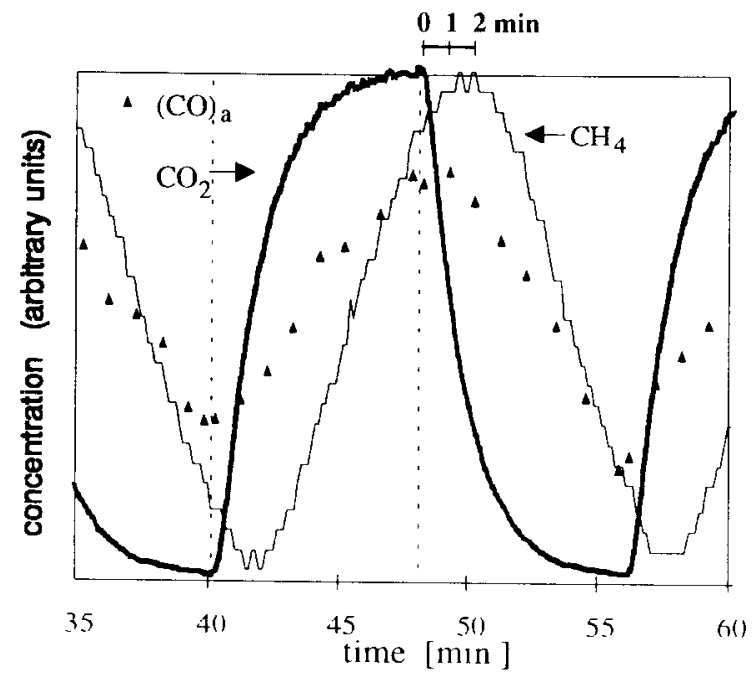

Fig 5. Response curves to periodic $\mathrm{CO}_{2}$ feed variations (adjusted amplitudes) (a) 1.2 min time shift between $(\mathrm{CO})_{a}$ and $\mathrm{CH}_{4}$. (b) 0 min time shift between $\mathrm{CO}_{2}$ and (formate) ${ }_{\mathrm{a}}$. (c) 0.8 min time shıft between $\mathrm{CO}_{2}$ and $(\mathrm{CO})_{\mathrm{a}}$. 

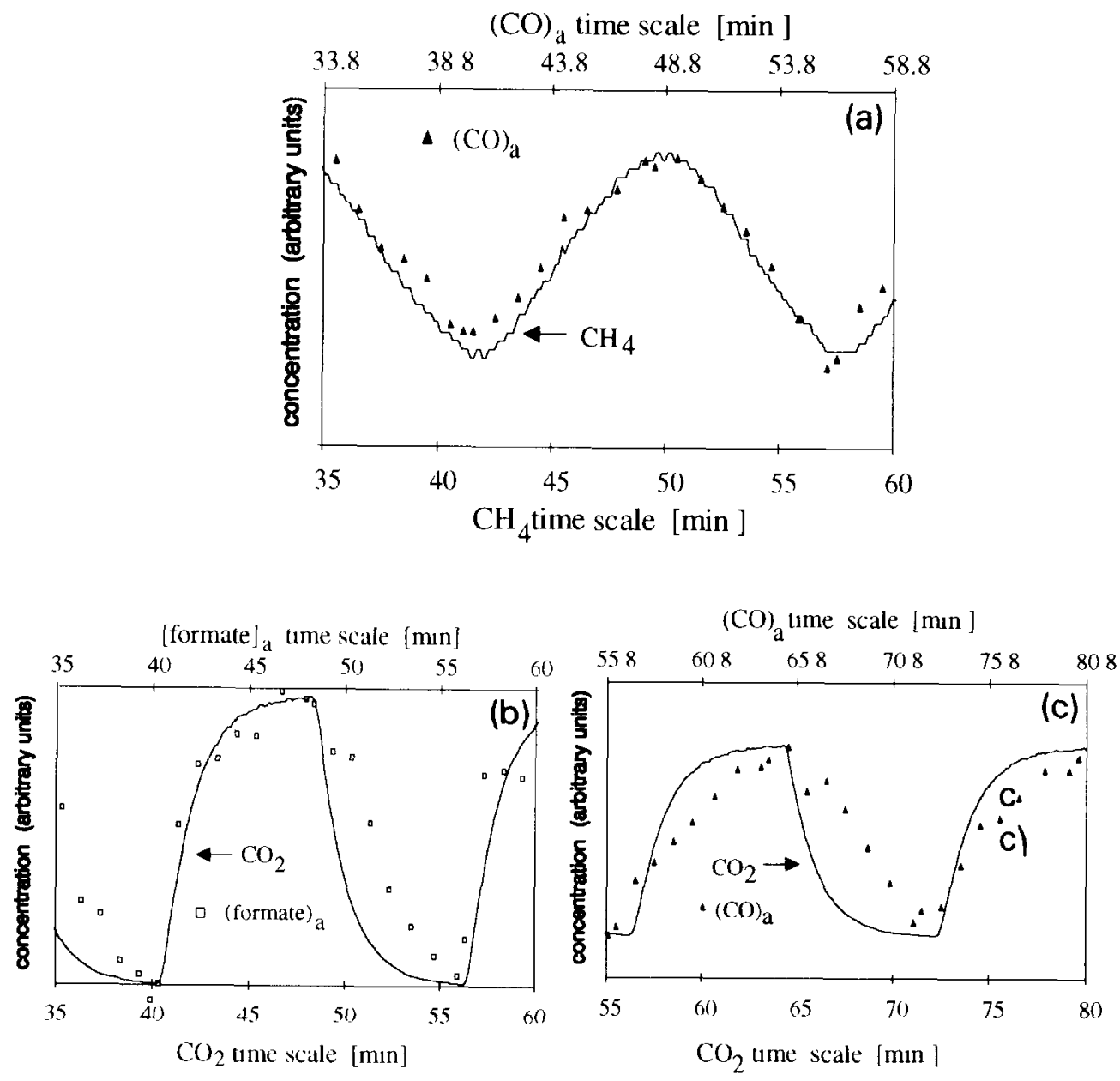

Fig 6. Comparison of response curves to penodic $\mathrm{CO}_{2}$ feed variations (adjusted amplitudes).

By adjusting the signals on two separate time scales and aligning the maxima/minima of the signals a more exact time shift can be determined.

The reaction sequence considerably changes the shape of the signal, but the cycle period is conserved. For the adsorbed $(\mathrm{CO})_{\mathrm{a}}$ to methane sequence (Fig. 6a) a 1.2 minutes time lag is observed. The two signals are very similar in shape. For the $\mathrm{CO}_{2}$ to (formate) sequence (Fig. 6b), no time delay is measured between the maxima. Formate concentration increases and decreases instantly upon $\mathrm{CO}_{2}$ gas phase concentration changes. It is also observed that the (formate) ${ }_{\mathrm{a}}$ formation is much faster than its desorption/decomposition. For the $\mathrm{CO}_{2}$ to $(\mathrm{CO})_{\text {a }}$ sequence (Fig. $6 \mathrm{c}$ ) a 0.8 minutes time lag is measured between the signal maxima.

A similar delay is also observed after injecting a pulse of gaseous $\mathrm{CO}$ in argon into the reactor operating at steady-state conditions. The result of this disturbance is shown in Fig. 7. 
$(\mathrm{CO})_{\mathrm{a}}$ concentration increases as soon as the argon inert tracer is detected. The methane production is also increased, but this increase is detected only after a one minute time lag, as during the $\mathrm{CO}_{2}$ feed variation experiments.

The following scheme (Eq. 1) summarizes the observations made in the periodic operation experiment:

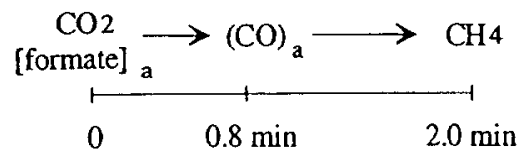

The similarity in the time lags for $(\mathrm{CO})_{\mathrm{a}}$ formation and hydrogenation indicates that at least two rate limiting steps control the overall methanation. Comparatively to these two steps, the formation of the (formate) a $_{\mathrm{a}}$ is very quick, while its desorption/decomposition is slower.

The following reaction pathway (Eq. 2) including these observed surface intermediates is proposed:

$$
\begin{aligned}
& \mathrm{CO}_{2}+-\mathrm{OH} \quad \rightleftarrows \quad\left(\mathrm{HCO}_{3}^{-}\right)_{\mathrm{d}} \\
& \left(\mathrm{HCO}_{3}^{-}\right)_{\mathrm{a}}+\mathrm{H}_{2} \rightleftarrows \quad\left(\mathrm{HCOO}^{-}\right)_{\mathrm{a}}+\mathrm{H}_{2} \mathrm{O} \\
& (\mathrm{HCOO})_{\mathrm{a}}^{-} \quad \longrightarrow \quad(\mathrm{CO})_{\mathrm{a}}+-\mathrm{OH} \\
& (\mathrm{CO})_{\mathrm{a}}+3 \mathrm{H}_{2} \longrightarrow \mathrm{CH}_{4}+\mathrm{H}_{2} \mathrm{O} \\
& \mathrm{CO}_{2}+4 \mathrm{H}_{2} \quad \rightleftarrows \quad \mathrm{CH}_{4}+2 \mathrm{H}_{2} \mathrm{O}
\end{aligned}
$$

In this model $\mathrm{CO}_{2}$ chemisorbs on the surface by reacting with a surface hydroxyl group to form a (bicarbonate) ${ }_{a}$. This (bicarbonate) ${ }_{a}$ is then hydrogenated into a (formate) ${ }_{a}$. The (formate) $)_{a}$ decomposes to adsorbed $(\mathrm{CO})_{a}$, restoring the surface hydroxyl. The $(\mathrm{CO})_{\mathrm{a}}$ is finally hydrogenated successively to form methane.

The periodic $\mathrm{CO}_{2}$ feed variation experiment can be simulated using this proposed model. During the experiments, $\mathrm{H}_{2}$ was used in excess and the $\mathrm{H}_{2} \mathrm{O}$ pressure was maintained constant, so the influences of these species were not taken into account in order to simplify the model (Eq. 3):

$$
\begin{array}{lll}
\mathrm{CO}_{2}+\mathrm{S} & \underset{\substack{k_{1} \\
\mathrm{k}_{2}}}{\stackrel{k_{2}}{\rightleftarrows}} \mathrm{CO}_{2} \ldots \mathrm{S} \\
\mathrm{CO}_{2} \ldots \mathrm{S} & \stackrel{\substack{k-2 \\
k_{3}}}{\longrightarrow} \mathrm{CO} \ldots \mathrm{M}+\mathrm{S} \\
\mathrm{M}+\mathrm{HCOO}^{-} \ldots \mathrm{S} & \stackrel{\mathrm{S}}{\longrightarrow} \\
\mathrm{CO} \ldots \mathrm{M} & \stackrel{k_{4}}{\longrightarrow} & \mathrm{CH}_{4}+\mathrm{M}
\end{array}
$$

$\mathrm{S}=$ support or interfacial site, $\mathrm{M}=$ metal site, $\mathrm{HCOO}^{-} \ldots \mathrm{S}=(\text { formate })_{\mathrm{a}}, \mathrm{CO} \ldots \mathrm{M}=(\mathrm{CO})_{\mathrm{a}}$

$$
\begin{aligned}
r_{1} & =k_{1}\left[\mathrm{CO}_{2}\right][\mathrm{S}]-k_{-1}\left[\mathrm{CO}_{2} \ldots \mathrm{S}\right] \\
r_{2} & =k_{2}\left[\mathrm{CO}_{2} \ldots \mathrm{S}\right]-k_{-2}\left[\mathrm{HCOO}^{-} \ldots \mathrm{S}\right] \\
r_{3} & =k_{3}[\mathrm{M}][\mathrm{HCOO}-\ldots \mathrm{S}] \\
r_{4} & =k_{4}[\mathrm{CO} \ldots \mathrm{M}]
\end{aligned}
$$

mass balance for ideally mixed recycle reactor: 


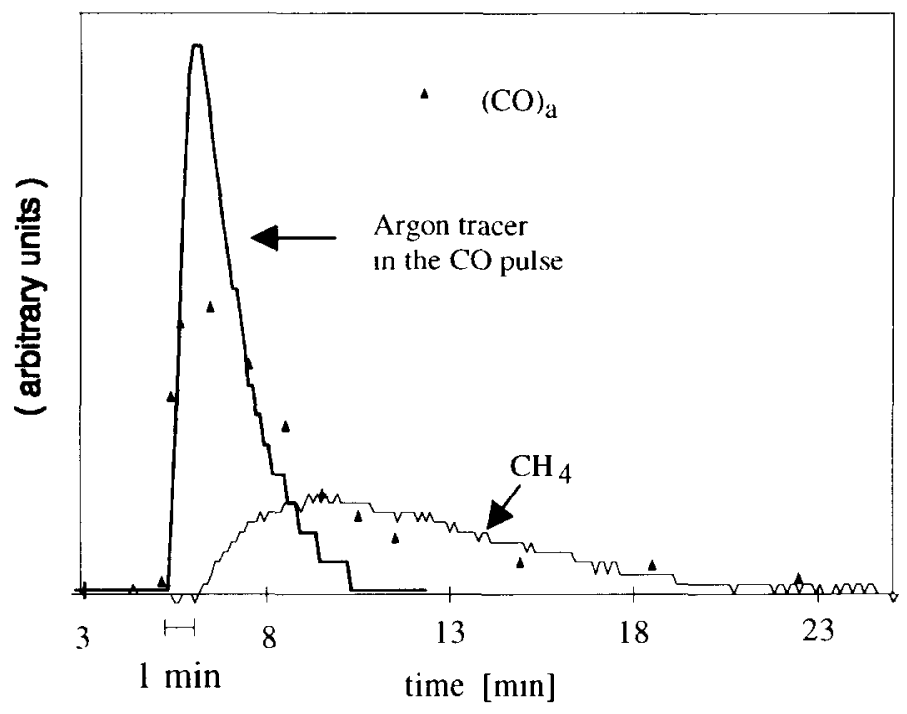

Fig 7. Response to $\mathrm{CO}_{(\mathrm{g})}$ pulses in $\mathrm{CO}_{2} / \mathrm{H}_{2}$ feed.

$$
\begin{array}{ll}
{\left[\mathrm{CO}_{2}\right]_{0}} & =\text { inlet concentration } \\
\frac{\mathrm{d}\left[\mathrm{CO}_{2}\right]}{\mathrm{d} t} & =\left[\mathrm{CO}_{2}\right]_{0}-r_{1}-\left[\mathrm{CO}_{2}\right] \\
\left.\frac{\mathrm{d}[\mathrm{HCOO}}{\mathrm{d} t} \ldots \mathrm{S}\right] & =r_{2}-r_{3} \\
\frac{\mathrm{d}[\mathrm{CO} \ldots \mathrm{M}]}{\mathrm{d} t} & =r_{3}-r_{4} \\
\frac{\mathrm{d}\left[\mathrm{CH}_{4}\right]}{\mathrm{d} t} & =r_{4}-\left[\mathrm{CH}_{4}\right]
\end{array}
$$

The observations made during the experiments are used to set relative values to the kinetic constants. Formate formation is a very quick process, while its decomposition is slower. The $(\mathrm{CO})_{\mathrm{a}}$ formation step and the $(\mathrm{CO})_{\mathrm{a}}$ hydrogenation steps are the two slow steps of the process.

The main trends observed in the experiment (Fig. 4), which are the different time lags between $\mathrm{CO}_{2}$, (formate) ${ }_{\mathrm{a}},(\mathrm{CO})_{\mathrm{a}}$ and $\mathrm{CH}_{4}$ are reproduced in the simulated experiment (Fig. 8).

A different treatment can also be applied to the data. An average value for the measured methane, adsorbed $(\mathrm{CO})_{\mathrm{a}}$ and (formate) $)_{\mathrm{a}}$ can be calculated over a cycle period. This can be done for different cycle periods and a plot representing this mean value as a function of the cycle period can be established (Fig. 9).

In such a plot it is observed that all of these mean values decrease when the cycle period increases. For a small cycle period the average methane concentration as well as the average surface $(\mathrm{CO})_{\mathbf{a}}$ seem to be very close to the steady-state value and are even slightly greater.

The steady-state dependence of methane and (formate) a concentration with regard to $\mathrm{CO}_{2}$ has been measured. A very similar function was found for the two compounds with an exponential value of respectively 0.24 and 0.22 (Eq. 6). 


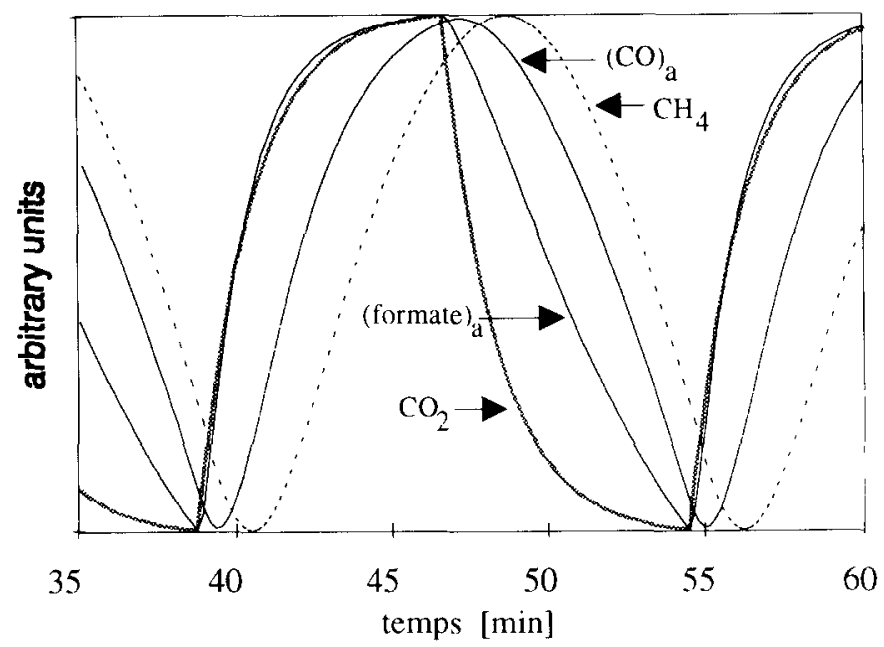

Fig. 8. Simulation of $\mathrm{CO}_{2}$ periodic variations in the feed relative rate constants $k_{1}=30, k_{-1}=20, k_{2}=30, k_{-2}=5$, $k_{3}=1, k_{4}=0.25$

$$
\begin{aligned}
& R_{\mathrm{CH}_{4}}=\operatorname{cst}\left(P_{\mathrm{CO}_{2}}\right)^{n} \text { with } n=0.24 \pm 0.03 \\
& R_{\text {(formate) }}=\operatorname{cst}\left(P_{\mathrm{CO}_{2}}\right)^{m} \text { with } m=0.22 \pm 0.03
\end{aligned}
$$

By applying this steady-state function to the cyclic $\mathrm{CO}_{2}$ signal, it is possible to calculate a methane and (formate) a variation with time. This procedure makes the important assump-

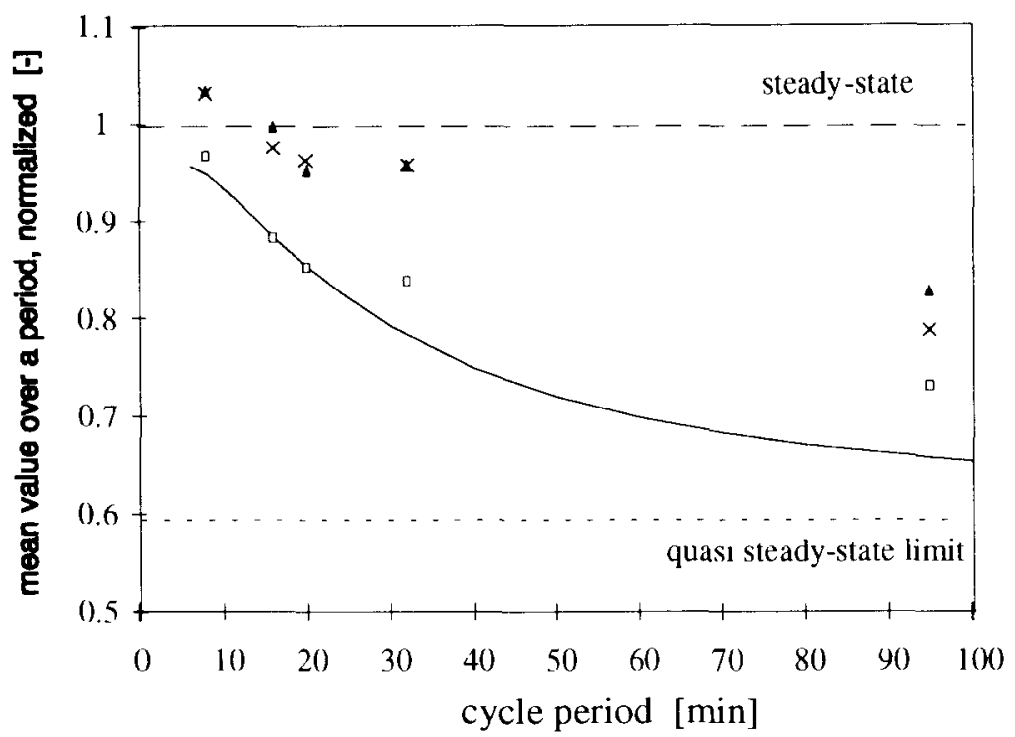

Fig. 9. Mean reaction value and surface concentration as function of cycle periods. ( $\times$ ) $\mathrm{CH}_{4},(\Delta)(\mathrm{CO})_{\mathrm{a}},(\square)$ (formate) $)_{\mathrm{a}} ;(-) \mathrm{CH}_{4}$ and (formate) ${ }_{\mathrm{a}}$ steady state model. 
tion that both compounds attain a steady-state at each $\mathrm{CO}_{2}$ concentration. An average value can be calculated for each period of this steady-state simulation of the periodic experiment.

The result of this steady-state simulation is superimposed on the experimental data (Fig. 9 ). The decrease of the average methane and (formate) $)_{\mathbf{a}}$ with increasing cycle period is due to the $\sim 0.2$ exponential value in the steady-state function The quasi steady-state limit can be calculated and is shown in Fig. 9.

The experimental $\mathrm{CH}_{4}$ mean quantity is always greater than in the steady-state model, while the (formate) aits more correctly to this model. This is due to the fact that the steadystate assumption can be considered to be almost correct for the formation of surface formate. On the other hand the formed methane is never at steady-state.

\section{Conclusions}

Pcriodic variations of $\mathrm{CO}_{2}$ in the $\mathrm{H}_{2}$ reaction feed with simultancous surface and gas phase measurements result in response signals for the product and for one surface intermediate with maxima/minima shifted in time.

A similar delay is measured for the $(\mathrm{CO})_{\text {a }}$ formation and for its methanation. It is concluded from this observation that the overall reaction is not limited by a unique limiting step but rather by two steps of equivalent speed.

A kinetic model including $(\mathrm{CO})_{\mathrm{a}}$ and (formate) $)_{\mathrm{a}}$ as reaction intermediates in the sequence $\mathrm{CO}_{2} \longleftrightarrow$ (formate) $)_{\mathrm{a}} \rightarrow(\mathrm{CO})_{\mathrm{a}} \rightarrow \mathrm{CH}_{4}$ was proposed and verified under periodic conditions. The main experimental trends, which are pronounced time lags between $\mathrm{CO}_{2},(\mathrm{CO})_{\mathrm{a}}$ and $\mathrm{CH}_{4}$, could be described satisfactorily.

\section{Acknowledgements}

We are grateful to the Swiss National Science Foundation for financial support and to $\mathrm{H}$. Randall for his help in the elaboration of the computer model.

\section{References}

[1] J.J. Carberry, Chemical and Catalytic Reactıon Engineering, McCraw-Hill, New York, 1976, p. 388

[2] M. Baerns, H. Hoffman and A. Renken, Chemische Reaktionstechnik, Georg Thieme Verlag, 2nd ed., 1990. p. 55.

[3] A. Renken, in Yu.Sh. Matros (Editor), Unsteady State Processes in Catalysis, VSP, Utrecht, Tokyo, 1990, p. 183.

[4] K. Tamaru, Dynamic Relaxation Methods in J.R. Anderson and M. Boudart (Editors), Heterogeneous Catalysis, Catalysis: Science and Technology, Vol. 9. Springer Verlag, 1991, p. 88.

[5] M.R. Prairie, J.G. Highfield and A. Renken, Chem. Eng. Sci., 46 (1) (1991) 113-121.

[6] M.R. Prairie, A. Renken, J.G. Hıghfield, K.R. Thampi and M. Grätzel, J. Catal., 129 (1991) 130-144, .

[7] J.G. Highfield, M.R. Prairie and A. Renken, Catal. Today, 9 (1991) 39-46.

[8] M.A. Henderson and S.D Worley, J. Phys. Chem., 89 (1985) 1417-1423.

[9] A. Erdöhelyi, M. Pàsztor and F. Solymosi, J. Catal., 98 (1986) 166.

[10] F. Solymosi, A. Erdöhelyi and M. Kocsis J. Chem. Soc., Faraday Trans. 1, 77 ( 1981 ) 1003-1012. 
[11] K.R. Thampı, J. Kiwi and M Gratzel, Nature, 327 (1987) 506.

[12] R.A. Dalla Betta and M. Shelef, J Catal, 48 (1977) 111.

[13] C.S. Kellner and A.T. Bell, J Catal., 71 (1981) 296.

[14] J.L. Robbins. J. Catal.. 115 ( 1989) 120.

[15] G.H Yokomizo, C. Louss and A T. Bell, J Catal, 120 (1989) 1

[ 16| N.M. Gupta, V S. Kamble, R.M Iyer, K.R Thampı and M Gratzel, J Catal., 137 (1992) 473

[17| G. Busca, J. Lamotte, J.-C. Lavalley and V. Lorenzelli, J Am. Chem. Soc., 109 (1987) 5197. 